\title{
Edaphic controls on soil organic carbon stocks in restored grasslands
}

Sarah L. O’Brien ${ }^{\mathrm{a}, b^{*}}$, Julie D. Jastrow ${ }^{\mathrm{b}}$, David A. Grimley ${ }^{\mathrm{c}}$, Miquel A. Gonzalez-Meler ${ }^{\mathrm{a}}$

${ }^{\text {a }}$ Department of Biological Sciences M/C 066, University of Illinois at Chicago, $845 \mathrm{~W}$.

Taylor St. M/C 066, Chicago, IL 60607, USA

${ }^{\mathrm{b}}$ Biosciences Division, Argonne National Laboratory, 9700 S. Cass Ave., Argonne IL, 60439, USA

${ }^{c}$ Illinois State Geological Survey, Prairie Research Institute, University of Illinois, 615 E.

Peabody Dr., Champaign, IL 61820, USA

* Corresponding author and current address. Biosciences Division, Argonne National

Laboratory, 9700 S. Cass Ave., Argonne IL, 60439, USA Tel.: +1 630-252-7854; fax: +1

630-252-5517. sobrien@anl.gov

The submitted manuscript has been created by UChicago Argonne, LLC, Operator of Argonne National Laboratory ("Argonne"). Argonne, a U.S. Department of Energy Office of Science laboratory, is operated under Contract No. DE-AC02-06CH11357. The

U.S. Government retains for itself, and others acting on its behalf, a paid-up nonexclusive, irrevocable worldwide license in said article to reproduce, prepare derivative works, distribute copies to the public, and perform publicly and display publicly, by or on behalf of the Government. 


\begin{abstract}
Cultivation of undisturbed soils dramatically depletes organic carbon stocks at shallow depths, releasing a substantial quantity of stored carbon to the atmosphere. Restoration of native ecosystems can help degraded soils rebuild a portion of the depleted soil organic matter. However, the rate and magnitude of soil carbon accrual can be highly variable from site to site. Thus, a better understanding of the mechanisms controlling soil organic carbon stocks is necessary to improve predictions of soil carbon recovery. We measured soil organic carbon stocks and a suite of edaphic factors in the upper $10 \mathrm{~cm}$ of a series of restored tallgrass prairies representing a range of drainage conditions. Our findings suggest that factors related to soil organic matter stabilization mechanisms (texture, polyvalent cations) were key predictors of soil organic carbon, along with variables that influence plant and microbial biomass (available phosphorus, $\mathrm{pH}$ ) and soil moisture. Exchangeable soil calcium was the strongest single predictor, explaining $74 \%$ of the variation in soil organic carbon, followed by clay content, which explained $52 \%$ of the variation. Our results demonstrate that the cumulative effects of even relatively small differences in these edaphic properties can have a large impact on soil carbon stocks when integrated over several decades.
\end{abstract}

\title{
Abbreviations
}

ANOVA Analysis of variance

CEC Cation exchange capacity

PCA Principal components analysis

SOC Soil organic carbon

SOM Soil organic matter

Keywords: calcium, drainage, restored prairie, soil organic matter, texture 


\section{Introduction}

Cultivation dramatically depletes soil organic carbon (SOC) stocks in the plow layer, diminishing soil fertility and impacting the global C cycle (Burke et al., 1995; Grandy and Robertson, 2006; Mann, 1986; Schlesinger and Andrews, 2000; Schnitzer et al., 2006; Slobodian et al., 2002; Tiessen et al., 1982). Reestablishment of native vegetation such as forests and perennial grasslands can facilitate SOC recovery and, thereby, might offer sinks for rising atmospheric $\mathrm{CO}_{2}$. However, rates of SOC accrual on land converted from agriculture to native ecosystems within similar geographic locations vary widely (McLauchlan, 2007; Post and Kwon, 2000) for reasons that are not completely understood. This local variation offers the opportunity to investigate the mechanisms that lead to differences in the amount of SOC at the landscape scale. Such information is needed to better predict and harness the C-sequestration potential of individual restored sites (Jastrow et al., 2007). Similarly, this information can be used to improve extrapolations at regional spatial scales or to calibrate and validate model predictions based on plant functional types.

The ability of restored grasslands to accumulate SOC is well established (Baer et al., 2002; Jastrow, 1996; Kucharik, 2007; Matamala et al., 2008; McLauchlan et al., 2006; O'Brien et al., 2010); however, the factors that influence the rate of $\mathrm{C}$ accrual at the site-level are poorly characterized. For example, edaphic properties such as texture, cation exchange capacity (CEC), and $\mathrm{pH}$ may interact with factors such as soil moisture and vegetation to control the accrual and retention of SOM. The degree to which such edaphic factors determine the SOC accumulated in restored grasslands is unclear, however. For instance, texture has been hypothesized to be a predictor of the capacity of 
soil to stabilize SOM due to interactions between SOM, mineral surface area, and electrostatic binding sites (Baldock and Skjemstad, 2000; Bosatta and Agren, 1997; Hassink, 1997; Six et al., 2002; Sollins et al., 1996). Likewise, polyvalent cations such as $\mathrm{Ca}^{2+}$ facilitate SOM stabilization in many soils due to electrostatic bridging between clay surfaces and SOM (Muneer and Oades, 1989). However, a clear link between localized variation in soil texture and the rate of SOC accrual in restored grasslands has yet to be established. Landscape-level variation in edaphic factors and ecosystem properties likely exert strong influences on localized SOC dynamics, but the interactions of these factors or the experimental design and measurement scale may conceal the degree to which different factors control SOC accrual.

Soil moisture is another factor that can influence SOC in grasslands (Jelinski and Kucharik, 2009; O’Brien et al., 2010; von Haden and Dornbush, 2014). Optimal soil moisture can increase organic inputs to soil by promoting plant productivity (Knapp et al., 1993). Alternatively, increased SOC stocks in mesic prairies have been linked to suppression of microbial decomposition in wetter soils (von Haden and Dornbush, 2014). Jelinksi and Kucharik (2009) hypothesized that soils in poorly drained areas may have suffered lower agriculture-induced SOC losses compared to better-drained soils. But, the mechanisms that allowed poorly drained prairies to retain SOC when cultivated might also promote faster recovery of SOC that was lost. Indeed, we have shown that long-term soil moisture (measured by proxy with soil magnetic susceptibility and topographic position) was a key factor controlling the rate of SOC accrual measured over two decades in restored prairies (O’Brien et al., 2010). Despite the strong effects of soil moisture, we 
also observed that variations in SOC occurred within the drainage gradient responsible for the long-term differences in soil moisture.

Here, we investigated the multifaceted controls on SOC stocks in restored perennial grasslands by sampling a series of restored tallgrass prairies established across a drainage gradient at a site with relatively low relief in the United States Midwest. Although soil moisture was a good landscape predictor of SOC stocks accumulated over decades (O'Brien et al., 2010), we hypothesize that localized fine-scale variations in SOC stocks can be explained by variations in edaphic properties that influence SOM stabilization. To explore this hypothesis, we expanded on our earlier work by measuring SOC stocks, edaphic properties, and a proxy for long-term soil moisture conditions in a new gradient representing a wider range of drainage conditions within the site's chronosequence of restored prairies.

\section{Materials and Methods}

\subsection{Site description}

The study was carried out in a series of tallgrass prairie restorations in the National Environmental Research Park at Fermi National Accelerator Laboratory

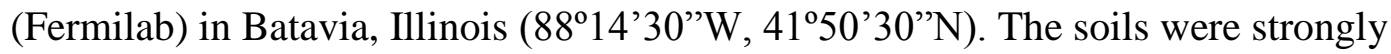
aggregated silt loam and silty clay loam Mollisols, transitional Alfisols with mollic epipedons, or Alfisols developed on surface loess deposits. For the period between 1971 and 2000 , average air temperature was $8.9^{\circ} \mathrm{C}$ and average annual precipitation was 975 $\mathrm{mm}$. The site is located in the Prairie Peninsula region, where periodic fire and grazing maintained grasslands that encroached on forested lands during the warmer and drier 
Hypsithermal interval beginning about 8000 B.P. (King, 1981). Elevation ranged from 225 to 237 meters above mean sea level in the study area. Beginning in 1975, prairie vegetation was established on fields in and around the site's particle accelerator, all of which were in long-term row crop agriculture until 1969-1970. To initiate restoration, the land was disked and then seeded with local ecotypes of native prairie species. Beginning about 3 years after conversion, the prairies were maintained with annual prescribed burns until the early 1990s, after which the prairies were burned less frequently (generally once every $2-3$ years).

Much of the area where Fermilab is located was seasonally wet or even flooded until drainage tiles were installed in the early 1900s to enable reliable cultivation of agricultural fields. Such artificial drainage is common in the region; about $37 \%$ of cropped land in the U.S. Midwest (historically dominated by tallgrass prairie) is subsurface-drained, contributing significantly to the over 43 million ha of subsurfacedrained land in the U.S. (Madramootoo et al., 2007 and references therein). The construction of Fermilab's main particle accelerator ring disrupted the drainage system within the ring, and the retention of water for cooling purposes restored a seasonally higher water table for the restored prairies located inside the $2 \mathrm{~km}$-diameter ring. However, subtle topographic relief causes variation in water table depth and surface drainage among prairie plots within the ring. In contrast, areas located outside of the main accelerator ring are generally better drained due to the presence of functional drainage tiles. A set of prairies was identified within this mosaic of drainage conditions to study how edaphic properties control SOC in the context of a gradient of varying soil moisture.

\subsection{Field sampling}


Soil samples were collected from twelve restored prairies during April and May of 2005. Prairies were selected to encompass a range of drainage conditions across the narrowest possible range of ages to minimize the potentially confounding effect of time since restoration (Table 1). Four moisture categories were identified by considering topography, relationship to engineering (i.e. inside or outside the main accelerator ring), general observations of seasonal water tables, and soil series. The wettest plots were deemed "seasonally saturated" prairies (Plots 10,11,13) and were located in the southern half of the main accelerator ring interior. Plots located in the northern half of the main ring interior had somewhat better drainage and were considered "mesic" prairies (Plots 2, $4,7)$. The remaining moisture categories were located in plots outside the main accelerator ring. Each of these plots (which were subject to artificial drainage) had a topographic gradient, designated as "down-slope" for topographically low areas within plots and "up-slope" for higher areas within the same plots (Plots 12, 14, 15). Plot 12 was located within a secondary injector ring connected to the main ring, where belowground accelerator structures might restrict drainage but the water table was not artificially raise to retain water for cooling. Thus, moisture contrasts came from inside vs. outside the main accelerator ring and from topographic variability. Soils included Drummer silty clay loam (fine-silty, mixed, superactive, mesic typic Endoaquoll), Wauconda silt loam (finesilty, mixed, superactive, mesic udollic Endoaqualf), Mundelein silt loam (fine-silty, mixed, superactive, mesic aquic Argiudoll), and Ozaukee silt loam (fine, illitic, mesic oxyaquic Hapludalf). All soils were located on 0-2\% slopes, except for the Ozaukee silt loam which occurred on slopes of 4-6\%. Plot characteristics are summarized in Table 1. 
In each plot, soils were sampled from four areas (each ranging in size from about $1 \mathrm{~m}^{2}$ to $16 \mathrm{~m}^{2}$ depending on plant density and distribution) according to a stratified random design. In each area, six 7-cm-diameter soil cores were collected to a depth of 10 $\mathrm{cm}$. Surface litter was removed before coring. We focused on the surface $10 \mathrm{~cm}$ because the high root densities in the uppermost portion of the profile lead to the fastest rates of SOC accrual (e.g. Baer et al., 2002; Matamala et al., 2008; O’Brien et al., 2010), providing the best opportunity to identify the edaphic properties that are most tightly correlated with SOC stocks. Cores were placed individually in polyethylene bags and frozen at the end of each day.

\subsection{Laboratory analyses}

Soil cores were thawed overnight at $4^{\circ} \mathrm{C}$ before processing. Cores were weighed, quickly homogenized before removing a subsample for gravimetric moisture determination, and then passed through an $8-\mathrm{mm}$ sieve to remove roots. Samples that were too wet to sieve immediately were allowed to partially air dry for 1-3 hours after the moisture subsample was removed. Bulk density was determined by dividing the moisture-corrected mass of each intact soil core by the known volume of the core. After drying the sieved soil at $55^{\circ} \mathrm{C}$, a composite sample was created by pooling $\sim 15 \mathrm{~g}$ of sieved soil from each of the six cores within a sampling area. From each homogenized composite sample, a 20-30 g subsample was removed, crushed with a rolling pin, passed through a 2-mm sieve to remove remaining root pieces, and then pulverized in a ball mill (Spex Certiprep) for C analysis. Soils were analyzed for total C concentration by dry combustion with a Carlo Erba NC2500 elemental analyzer (Milan, Italy). Total C was equivalent to organic $\mathrm{C}$ because no carbonates were present (no effervescence was 
detected upon exposure to $6 \mathrm{~N} \mathrm{HCl})$. To account for soil bulk density differences among the plots, soil $\mathrm{C}$ stocks were calculated on an equivalent mass basis using the lightest sample $(69 \mathrm{~kg} \mathrm{~m}-2$ to a depth of $10 \mathrm{~cm}$ ) as the equivalent (modified from Ellert and Bettany, 1995).

A second subsample of each composite 2-mm sieved sample was sent to the Kansas State University Soil Testing Laboratory for chemical and physical analysis. Soil $\mathrm{pH}$ was measured in a 1:1 slurry with water (Watson and Brown, 1998). Available $\mathrm{Fe}^{3+}$ and $\mathrm{Mn}^{2+}$ were extracted with DTPA (diethylenetriaminepentaacetic acid) and measured by using inductively coupled plasma spectrometry or flame atomic absorption spectrometry (Whitney, 1998). Cation exchange capacity was determined by the ammonium ion replacement method, and exchangeable cations $\left(\mathrm{Ca}^{2+}, \mathrm{K}^{+}, \mathrm{Mg}^{2+}, \mathrm{Na}^{+}\right)$ were measured by the ammonium acetate method (1M, pH 7.0) and analyzed by inductively coupled plasma spectrometry or flame atomic absorption spectrometry (Warncke and Brown, 1998). Texture was determined by using a modification of the hydrometer method without organic matter removal (Bouyoucos, 1962). Available P was determined by the Mehlich-3 procedure with a 1:10 soil-to-solution ratio (Frank et al., 1998).

Soil magnetic susceptibility was determined by using a Bartington MS2 magnetic susceptibility meter with an MS2B dual frequency attachment (as in O'Brien et al., 2010). Magnetic susceptibility, the ratio of induced magnetism to the intensity of the field applied, is typically controlled by the concentration of ferrimagnetic minerals in surface soils (Grimley et al., 2004; Maher, 1998). Aided by microorganisms, the ferrimagnetic minerals can readily dissolve in anaerobic soil, where Fe (III) is reduced to Fe (II). Given 
similar soil forming factors (such as parent material), Fe-reduced (poorly drained) soils have consistently lower magnetic susceptibility values than adjacent well-drained soils (Grimley et al., 2004; Le Borgne, 1955; Maher, 1998, 1986; Mullins, 1977; Vadyunina and Babanin, 1972; Yu et al., 1986). Thus, magnetic susceptibility can locally be used as a proxy for long-term drainage and moisture conditions. Magnetic susceptibility is a suitable long-term drainage/moisture proxy for the study site's surface soils because they have loess parent material and similar mineralogical composition.

\subsection{Data Analysis}

To evaluate the effect of drainage/moisture conditions, a one-way mixed model ANOVA with age as a random covariate and plot as the sampling unit $(n=12)$ was used to compare variations in measured edaphic properties among the four moisture categories (PROC MIXED, SAS System, version 9.2, SAS Institute, Cary, NC). Post hoc comparisons of treatment means were made by using the Tukey-Kramer adjustment to minimize experiment-wise Type I errors. Differences were considered significant at $\alpha \leq$ 0.05 .

Principal components analysis (PCA) was used to identify which of the measured edaphic properties (Table 2) were the strongest contributors to the overall variation in the study soils at the subplot level ( $n=46$, because two outliers from plot 12 downslope were removed from the analysis). All data were $\log _{\mathrm{e}}$-transformed prior to analysis to normalize scales among variables. The correlation matrix was used to extract the principal components, and a distance-based biplot was used to evaluate and represent the direction and strength of the relationships between edaphic variables and the principal component scores (PC-ORD Version 5.0, MjM Software, Gleneden Beach, OR USA). Edaphic 
variables that initially loaded substantially on more than one component were removed from the PCA analysis. Components with eigenvalues $>1$ were retained. Log-transformed values of SOC stocks were then regressed on the PCA components, on each of the variables used in the PCA to extract the components, and on prairie age.

\section{Results}

Several of the measured edaphic properties varied significantly among moisture categories (Table 2). Although prairie ages varied somewhat among the study plots, these age differences were insufficient to attribute the variation in edaphic properties to a correlative random effect of prairie age, except for the percentage of silt-sized particles (Table 2). In the case of silt content, accounting for prairie age only slightly improved the fit of the model, further suggesting that the range of prairie ages included in this study had little impact on measured edaphic properties.

Cation exchange capacity (CEC), $\mathrm{Ca}^{2+}$, and $\mathrm{Mg}^{2+}$ tended to follow the moisture gradient (seasonally saturated $>$ mesic $>$ down-slope $>$ up-slope). But only the seasonally saturated and up-slope plots differed significantly for $\mathrm{CEC}$ and $\mathrm{Ca}^{2+}$, whereas $\mathrm{Mg}^{2+}$ was significantly greater in the seasonally saturated prairies compared to the drier down-slope and up-slope locations outside the main accelerator ring (Table 2). Exchangeable amounts of $\mathrm{K}^{+}$and $\mathrm{Na}^{+}$were much lower than the exchangeable $\mathrm{Ca}^{2+}$ and $\mathrm{Mg}^{2+}$, and $\mathrm{K}^{+}$ did not vary significantly among moisture categories. However, $\mathrm{Na}+$ was highest in the seasonally saturated prairies and lowest in the mesic prairies, a pattern that differed from the other base cations. Texture also differed significantly among moisture categories. Silt-sized particles were lowest in the mesic prairies, intermediate in the seasonally 
saturated prairies, and highest in the down-slope and up-slope locations. In contrast, the percentage of clay-sized particles was less in the drier down-slope and up-slope locations compared to the wetter prairies inside the main accelerator ring. These variations yielded a gradient of silt:clay ratio (mesic < seasonally saturated < down-slope < up-slope).

Soil organic C stocks did not differ significantly among moisture categories, although the mesic prairies had marginally greater $\mathrm{C}$ stocks compared to the up-slope locations $(P=0.055)$ and tended to follow a gradient that roughly coincided with soil magnetic susceptibility. When considered together, the prairies located inside the main accelerator ring $(n=6)$ had significantly higher $(P<0.01)$ mean SOC stocks $(3136 \pm 122$ $\left.\mathrm{g} \mathrm{m}^{-2}\right)$ compared to prairies located outside the accelerator ring $\left(2253 \pm 192 \mathrm{~g} \mathrm{~m}^{-2} ; n=6\right)$, which was consistent with the significantly lower $(P<0.001)$ magnetic susceptibility (i.e., wetter conditions) inside the ring $\left(14.9 \pm 1.7 \times 10^{-8} \mathrm{~m}^{3} \mathrm{~kg}^{-1}\right)$ than outside the ring $\left(30.6 \pm 2.3 \times 10^{-8} \mathrm{~m}^{3} \mathrm{~kg}^{-1}\right)$. These differences in SOC stocks and magnetic susceptibility were not influenced by any random effects due to prairie age. Gravimetric soil moisture at the time of sampling also differed among moisture categories (Table 2), with the seasonally saturated plots being wettest and the up-slope locations being driest. However, we did not employ these data in our interpretation of SOC stocks because they represent a single time point for a highly dynamic variable, and the samples were not collected simultaneously, making comparisons among plots spurious.

Two PCA axes were retained that together accounted for $79 \%$ of the total variance in the data (Fig. 1). The retained variables were $\mathrm{Ca}^{2+}, \mathrm{Mg}^{2+}$, magnetic susceptibility, $\mathrm{pH}, \mathrm{P}$, silt, and clay (Table 2), whereas CEC, $\mathrm{Fe}^{3+}, \mathrm{Mn}^{2+}, \mathrm{K}^{+}, \mathrm{Na}^{+}$, sand, and silt:clay ratio (Table 2) were removed either because they did not contribute 
appreciably to the result (i.e. loaded more-or-less equally on two axes) or because they were redundant with other variables (e.g. silt:clay ratio should not be used together with silt and clay separately; Table 3). Soil magnetic susceptibility, $\mathrm{Ca}^{2+}, \mathrm{Mg}^{2+}$, silt, and clay loaded primarily on the first component, and $\mathrm{pH}$ and $\mathrm{P}$ loaded on the second component (Fig. 1). Clay, $\mathrm{Ca}^{2+}$ and $\mathrm{Mg}^{2+}$ loaded positively on the first component, although clay and $\mathrm{Mg}^{2+}$ also showed some relationship with the second axis. In contrast, magnetic susceptibility and silt loaded in the opposite direction (Fig. 1). Similarly, pH and P had nearly equal and opposite effects with respect to the second component (Fig. 1).

The first two PCA components together were the best predictor of SOC stocks $(P$ $<0.01 ; r^{2}=0.77$; Table 4, Fig. 2). Each of the first two principal components alone also had a significant relationship with SOC, describing $63 \%$ and $14 \%$ of the variation in SOC stocks (Axis 1 and 2, respectively; Table 4, Fig. 2). In addition, each of the variables used in the PCA were significant predictors of SOC $(P<0.05$; Table 4$)$. However, less than $50 \%$ of the variation in SOC stocks was explained by individual variables, except for $\mathrm{Ca}^{2+}\left(r^{2}=0.74\right.$, Table 4, Fig. 3$)$ and clay content $\left(r^{2}=0.52\right.$; Table 4). Although prairie age varied among the plots in a non-random pattern (the oldest plots were inside the main accelerator ring and were categorized as having mesic moisture conditions), this relationship did not describe a substantial portion of the variation in $\operatorname{SOC}\left(r^{2}=0.22 ; P<\right.$ 0.01 ; Table 4).

\section{Discussion}

We found that a suite of edaphic factors influenced surface SOC stocks following two-three decades of prairie restoration on soils degraded by over a century of 
agricultural disturbance. The first PCA axis, which accounted for 55\% of the total variation in SOC stocks, was based largely on edaphic properties that contribute to SOM stabilization (polyvalent cations and particle size) and soil moisture conditions (Fig. 1). Exchangeable soil $\mathrm{Ca}^{2+}$ was the single most important predictor of SOC stocks followed by clay content, both of which exceeded the explanatory power of magnetic susceptibility, our proxy for long-term soil moisture (Table 4). In our earlier work involving repeated sampling over two decades within some of the same plots studied here, we showed that soil moisture had a critical impact on SOC accrual at the landscape scale (O'Brien et al., 2010). The broader sampling approach of this study has revealed the importance of additional factors affecting SOC stocks within the moisture/drainage gradient.

Although the literature regarding the impacts of edaphic properties on SOC stocks across landscapes is equivocal, we suggest that the role of $\mathrm{Ca}^{2+}$ and soil texture are more generalizable than previously recognized. For example, $\mathrm{Ca}^{2+}$ was a key contributor to SOC accrual in an afforested site (Morris et al., 2007) and pasture (Fornara et al., 2011), but was not an important predictor for restored prairies (McLauchlan et al., 2006). Here, we found that $\mathrm{Ca}^{2+}$ alone explained $74 \%$ of the variation in SOC stocks (Table 4, Fig. 3), which was nearly as much as both PCA axes together (77\%, Table 4), reinforcing the important role that $\mathrm{Ca}^{2+}$ can play in the accumulation of SOC in temperate ecosystems. Although the amount of exchangeable $\mathrm{Ca}^{2+}$ was relatively high in all our plots (characteristic of Mollisols), it was higher in the seasonally saturated plots than in the other moisture categories. Given that parent material did not vary across our site, this finding is likely a product of many factors that vary subtly over space and time, such as 
retention in organomineral complexes or subtle erosion and depositional processes. In addition, the high water tables in the seasonally saturated plots might least to greater upward migration of $\mathrm{Ca}^{2+}$ (and $\mathrm{Mg}^{2+}$ ) from deeper parent materials (i.e., below surface loess deposits) containing limestone and dolomite and/or less leaching due to the poorly drained conditions.

The effects of texture on SOC have been similarly difficult to characterize. For instance, particle size was correlated with SOC over broad regions such as the entire US Great Plains (Burke et al., 1989; Parton et al., 1987), the Indo-Gangetic Plains (Gami et al., 2009), and western Africa (Saiz et al., 2012). However, texture has not always been observed to impact SOC at the landscape scale. For example, texture was not correlated to SOC accrual in a meta-analysis of afforested land (Nave et al., 2013) and had no effect on SOC content or accrual rates for New Zealand grasslands (Percival et al., 2000) or a restored prairie ecosystem in Minnesota (McLauchlan, 2006). In contrast, clay content was positively related to SOC in shortgrass steppe (Hook and Burke, 2000) and restored prairies in Nebraska (Baer et al., 2010), where clay content was found to promote soil structure that stabilizes SOM. Similarly, clay content explained 52\% of the variation in SOC stocks for our Illinois restored prairies (Table 4), where we have previously documented the rapid recovery of soil aggregate structure following prairie restoration (Jastrow, 1996; O’Brien and Jastrow, 2013). The inconsistency of these effects across grassland ecosystems requires further study, but may be due in part to the $\mathrm{C}$ saturation deficit of the soils, i.e., the difference between the theoretical maximum $\mathrm{C}$ storage capacity of a soil (its saturation level) and the current $\mathrm{C}$ content of a soil (Six et al., 2002). Thus, if the soil $\mathrm{C}$ saturation deficit in a system recovering from disturbance is 
low, a factor such as texture may have a minimal effect on measured rates SOC accrual (see Stewart et al., 2008). Indeed, the relative distribution of smooth versus rough surfaces associated with clay minerals in a given soil appears to play a large role in the $\mathrm{C}$ sequestration capacity of those minerals (Vogel et al., 2014). Clay fractions that have a high degree of surface roughness due to cracks, pits, micropores, and clusters of very small mineral particles appear to provide more preferential sites for binding or protecting organic matter and a greater capacity for C sequestration (Chenu and Plante, 2006; McCarthy et al., 2008; Vogel et al., 2014)

These generalizations concerning $\mathrm{Ca}^{2+}$ and clay-facilitated SOM stabilization are supported by mechanisms reasonably well characterized in the literature. Polyvalent cations such as $\mathrm{Ca}^{2+}$ and $\mathrm{Mg}^{2+}$ promote clay flocculation and bind organic matter to clay surfaces through electrostatic interactions, thereby interfering with microbial breakdown of SOM components (Kögel-Knabner et al., 2008; Muneer and Oades, 1989). Likewise, clay minerals facilitate formation of macro-, micro-, and silt-sized aggregates (Denef and Six, 2005; Muneer and Oades, 1989; Virto et al., 2008) and provide surfaces for SOM sorption (Lee et al., 2010; Vogel et al., 2014), thus isolating SOM from microbial activity and protecting SOM from rapid decomposition (Baldock and Skjemstad, 2000; Hassink, 1997). Cations and clay minerals also interact with organic matter to form nanometer- to micrometer-sized structures that are important for SOM stabilization (Chenu and Plante, 2006; McCarthy et al., 2008; Monreal et al., 2010; Plante et al., 2006). Thus, the PCA results and the individual relationships between $\mathrm{Ca} 2+($ also $\mathrm{Mg} 2+)$ and clay content (Fig 1; Table 4) suggest that stabilization mechanisms related to sub-micron scale aggregation 
and chemical stabilization on mineral surfaces are important controls on SOC stocks in these restored prairies.

The percentage of silt-sized particles $(2-53 \mu \mathrm{m})$ also loaded strongly on the first PCA axis. However, given that silt loaded in the opposite direction of clay and was negatively related to SOC stocks (Table 4), this was probably a result of its approximately zero-sum relationship with clay (i.e., because sand content is fairly consistent in these soils, silt content decreases as clay content increases; Table 3). Although past work at this site (O’Brien and Jastrow, 2013) has shown significant C accumulation in the silt fraction of larger aggregate structures $(>53 \mu \mathrm{m})$, the determination of particle-size distributions reported here involved greater disruptive forces and more complete soil dispersion. Hence, some of organomineral particles present in the clay-sized fraction of the soils in this study might actually be found as components of silt-sized aggregates when the same soils are fractionated by less disruptive procedures designed to understand the physical distributions of SOM in situ.

The PCA results suggest that $\mathrm{pH}$ and available $\mathrm{P}$ might be related to the building and maintaining of SOC stocks, yet the potential mechanisms supporting any possible causative relationship are much less direct than for clay content or $\mathrm{Ca}^{2+}$. Soil $\mathrm{pH}$ and available P content loaded mainly on the second PCA axis (Fig. 1), and including the second axis improved the SOC relationship (Table 4). Soil pH plays many complex roles belowground, affecting processes such as microbial community structure, nutrient availability, enzyme activity, and metal solubility (Allison et al., 2005; Bååth and Anderson, 2003; Lauber et al., 2009; Leprince and Quiquampoix, 1996; Novozamsky and Beek, 1978). $\mathrm{pH}$ can also impact flocculation of SOM in $\mathrm{Al}$ and Fe complexes (Nierop et 
al., 2002). In addition, $\mathrm{pH}$ can influence the availability of $\mathrm{P}$, a fundamental nutrient for plants and heterotrophs (Alt et al., 2011; Novozamsky and Beek, 1978). Phosphorus has been shown to directly impact microbial community composition at this site (Allison et al., 2007) and thus could impact formation of SOM- protecting aggregates via its effect on microbial biomass and the production of external hyphae by mycorrhizal fungi (Jastrow and Miller, 1998; Jastrow et al., 1998).

Overall, the PCA results were consistent with our earlier work that established soil moisture as a driver of SOC accrual rates at this site. Yet, the PCA analysis also revealed the importance of other edaphic factors to SOC dynamics because it integrated an array of processes that occur in the soil over different spatial and temporal scales. For instance, soil texture is relatively static over the time intervals encompassed by this study, whereas $\mathrm{pH}$ may respond rapidly to changes in soil moisture status or plant activity. Furthermore, feedbacks among various edaphic factors could enhance their effects on SOC accrual (e.g., clay influences soil water retention, $\mathrm{pH}$ affects clay flocculation). Of course, organic inputs from plants are an important driver of SOC stocks as restored prairies develop (Matamala et al., 2008). However, prairie age was not a particularly strong predictor of SOC (Table 4). This results was most likely due to the relatively narrow range in plot ages examined for this study and the fact that the most rapid year-toyear increases in both above- and belowground primary production generally occur in younger restorations (Matamala et al., 2008). Although this study focused on SOC stocks and edaphic properties at one point in time, we argue that factors correlated with SOC stocks likely contribute to some level of SOC stabilization given that this site is known to be accumulating SOC (Matamala et al., 2008; O'Brien and Jastrow, 2013; O’Brien et al., 
2010). Additional studies are needed to understand how such interactions impact SOC stocks at spatial scales relevant to regional $\mathrm{C}$-cycle accounting and land management decisions.

\section{Conclusions}

Soil properties that promote SOM stabilization and retention $\left(\mathrm{Ca}^{2+}, \mathrm{Mg}^{2+}\right.$, clay content) and factors that influence biotic impacts on SOM dynamics $(\mathrm{pH}, \mathrm{P})$ were found to work in concert with soil moisture to control SOC stocks, and soil $\mathrm{Ca}^{2+}$ was identified as an extremely important factor. Assuming that variables that were correlated with SOC stocks two to three decades after prairie establishment are indicative of key mechanistic controls on the balance of $\mathrm{C}$ inputs and respiratory losses from soil, these variables should also be important to the rate of SOC accrual in prairies restored on abandoned agricultural fields. Thus, this study provides valuable clues to the interacting edaphic controls on SOC recovery following prairie restoration and demonstrates that factors known to affect SOM at sub-millimeter and regional scales also have predictable effects at landscape scales. Future work should employ detailed manipulative investigations of the variables identified here to characterize the exact mechanisms by which these factors interact to control the rate of SOC accumulation.

\section{Acknowledgments}

SLO was supported by a Department of Energy Global Change Education Program Graduate Research Environmental Fellowship. This work was supported by the US Department of Energy, Office of Science, Office of Biological and Environmental Research, Climate and Environmental Science Division under contract DE-AC0206CH11357 to Argonne National Laboratory, and a University of Illinois at Chicago 
Deiss Award for graduate research to SLO. We thank Fermilab personnel who established and maintain the prairies. We are grateful to Tim Vugteveen, Susan Kirt, and Dave Clarke for help collecting soil samples and to Kelly Moran for assistance in the lab. We also acknowledge Mike Miller for providing invaluable statistical advice and Kelly Moran, Thomas Boutton, and Roser Matamala, and two anonymous reviewers for helpful comments on an earlier draft of this manuscript. 


\section{References}

Allison, V.J., Miller, R.M., Jastrow, J.D., Matamala, R., Zak, D.R., 2005. Changes in Soil Microbial Community Structure in a Tallgrass Prairie Chronosequence. Soil Sci. Soc. Am. J. 69, 1412. doi:10.2136/sssaj2004.0252

Allison, V.J., Yermakov, Z., Miller, R.M., Jastrow, J.D., Matamala, R., 2007. Using landscape and depth gradients to decouple the impact of correlated environmental variables on soil microbial community composition. Soil Biol. Biochem. 39, 505516. doi:10.1016/j.soilbio.2006.08.021

Alt, F., Oelmann, Y., Herold, N., Schrumpf, M., Wilcke, W., 2011. Phosphorus partitioning in grassland and forest soils of Germany as related to land-use type, management intensity, and land use-related pH. J. Plant Nutr. Soil Sci. 174, 195209.

Bååth, E., Anderson, T.-H., 2003. Comparison of soil fungal/bacterial ratios in a pH gradient using physiological and PLFA-based techniques. Soil Biol. Biochem. 35, 955-963. doi:10.1016/S0038-0717(03)00154-8

Baer, S.G., Kitchen, D.J., Blair, J.M., Rice, C.W., 2002. Changes in Ecosystem Structure and Function along a Chronosequence of Restored Grasslands. Ecol. Appl. 12, $1688-1701$.

Baer, S.G., Meyer, C.K., Bach, E.M., Klopf, R.P., Six, J., 2010. Contrasting ecosystem recovery on two soil textures: implications for carbon mitigation and grassland conservation. Ecosphere 1, art5. doi:10.1890/ES10-00004.1

Baldock, J.., Skjemstad, J.., 2000. Role of the soil matrix and minerals in protecting natural organic materials against biological attack. Org. Geochem. 31, 697-710. doi:10.1016/S0146-6380(00)00049-8

Bosatta, E., Agren, G.I., 1997. Theoretical analyses of soil texture on organic matter dynamics. Soil Biol. Biochem. 29, 1633-1638.

Bouyoucos, G., 1962. Hydrometer method improved for making particle size analyses of soil. Agron. J. 54, 464-465.

Burke, I., Lauenoth, W., Coffin, D., 1995. Soil organic matter recovery in semiarid grasslands: implications for the Conservation Reserve Program. Ecol. Appl. 5, 793801.

Burke, I., Yonker, C., Parton, W., Cole, C., Flach, K., Schimel, D., 1989. Texture, climate, and cultivation effects on soil organic matter content in US grassland soils. Soil Sci. Soc. Am. J. 53, 800-805. 
Chenu, C., Plante, A.F., 2006. Clay-sized organo-mineral complexes in a cultivation chronosequence: revisiting the concept of the "primary organo-mineral complex." Eur. J. Soil Sci. 57, 596-607. doi:10.1111/j.1365-2389.2006.00834.x

Denef, K., Six, J., 2005. Clay mineralogy determines the importance of biological versus abiotic processes for macroaggregate formation and stabilization. Eur. J. Soil Sci. 56, 469-479. doi:10.1111/j.1365-2389.2004.00682.x

Ellert, B.H., Bettany, J.R., 1995. Calculation of organic matter and nutrients stored in soils under contrasting management regimes. Can. J. Soil Sci. 75, 529-538.

Fornara, D.A., Steinbeiss, S., McNamara, N.P., Gleixner, G., Oakley, S., Poulton, P.R., Macdonald, A.J., Bardgett, R.D., 2011. Increases in soil organic carbon sequestration can reduce the global warming potential of long-term liming to permanent grassland. Glob. Chang. Biol. 17, 1925-1934. doi:10.1111/j.13652486.2010.02328.x

Frank, K., Beegle, D., Denning, J., 1998. Phosphorus, in: Recommended Chemical Soil Test Procedures for the North Central Region. North Central Region Publication No. 221 (revised). University of Missouri Agricultural Experiment Station, Columbia, MO, pp. 21-29.

Gami, S.K., Lauren, J.G., Duxbury, J.M., 2009. Influence of soil texture and cultivation on carbon and nitrogen levels in soils of the eastern Indo-Gangetic Plains. Geoderma 153, 304-311. doi:10.1016/j.geoderma.2009.08.003

Grandy, S., Robertson, P., 2006. Initial cultivation of a temperate-region soil immediately accelerates aggregate turnover and $\mathrm{CO} 2$ and $\mathrm{N} 2 \mathrm{O}$ fluxes. Glob. Chang. Biol. 12, 1507-1520. doi:10.1111/j.1365-2486.2006.01166.x

Grimley, D.A., Arruda, N.K., Bramstedt, M.W., 2004. Using magnetic susceptibility to facilitate more rapid, reproducible and precise delineation of hydric soils in the midwestern USA. Catena 58, 183-213. doi:10.1016/j.catena.2004.03.001

Hassink, J., 1997. The capacity of soils to preserve organic C and $\mathrm{N}$ by their association with clay and silt particles. Plant Soil 191, 77-87.

Hook, P., Burke, I., 2000. Biogeochemistry in a shortgrass landscape: Control by topography, soil texture, and microclimate. Ecology 81, 2686-2703.

Jastrow, D., 1996. Soil aggregate formation and the accrual of particulate and mineralassociated organic matter. Soil Biol. Biochem. 28, 665-676.

Jastrow, J.D., Amonette, J.E., Bailey, V.L., 2007. Mechanisms controlling soil carbon turnover and their potential application for enhancing carbon sequestration. Clim. Change 80, 5-23. doi:10.1007/s10584-006-9178-3 
Jastrow, J.D., Miller, R., 1998. Soil aggregate stabilization and carbon sequestration: Feedbacks through organomineral associations, in: Lal, R., Kimble, J., Follett, R., Stewart, B. (Eds.), Soil Processes and the Carbon Cycle. CRC Press, Boca Raton, FL, pp. 207-223.

Jastrow, J.D., Miller, R.M., Lussenhop, J., 1998. Contributions of interacting biological mechanisms to soil aggregate stabilization in restored prairie. Soil Biol. Biochem. 30, 905-916.

Jelinski, N.A., Kucharik, C.J., 2009. Land-use Effects on Soil Carbon and Nitrogen on a U.S. Midwestern Floodplain. Soil Sci. Soc. Am. J. 73, 217. doi:10.2136/sssaj2007.0424

King, J., 1981. Late Quaternary vegetational history of Illinois. Ecol. Monogr. 51, 43-62.

Knapp, A., Fahnestock, J., Hamburg, S., Statland, L., Seastedt, T., Schimel, D., 1993. Landscape patterns in soil-plant water relations and primary production in tallgrass prairie. Ecology 74, 549-560.

Kögel-Knabner, I., Guggenberger, G., Kleber, M., Kandeler, E., Kalbitz, K., Scheu, S., Eusterhues, K., Leinweber, P., 2008. Organo-mineral associations in temperate soils: Integrating biology, mineralogy, and organic matter chemistry. J. Plant Nutr. Soil Sci. 171, 61-82. doi:10.1002/jpln.200700048

Kucharik, C.J., 2007. Impact of Prairie Age and Soil Order on Carbon and Nitrogen Sequestration. Soil Sci. Soc. Am. J. 71, 430. doi:10.2136/sssaj2006.0074

Lauber, C.L., Hamady, M., Knight, R., Fierer, N., 2009. Pyrosequencing-based assessment of soil $\mathrm{pH}$ as a predictor of soil bacterial community structure at the continental scale. Appl. Environ. Microbiol. 75, 5111-20. doi:10.1128/AEM.0033509

Le Borgne, E., 1955. Susceptibilite magnetique anomale du sol superficial. Ann. Geophys. 11, 399-419.

Lee, S.S., Park, C., Fenter, P., Sturchio, N.C., Nagy, K.L., 2010. Competitive adsorption of strontium and fulvic acid at the muscovite-solution interface observed with resonant anomalous X-ray reflectivity. Geochim. Cosmochim. Acta 74, 1762-1776. doi:10.1016/j.gca.2009.12.010

Leprince, F., Quiquampoix, H., 1996. Extracellular enzyme activity in soil: effect of pH and ionic strength on the interaction with montmorillonite of two acid phosphatases secreted by the ectomycorrhizal fungus Hebeloma cylindrosporum. Eur. J. Soil Sci. 47, 511-522. 
Madramootoo, C.A., Johnston, W.R., Ayars, J.E., Evans, R.O., Fausey, N.R., 2007. Agricultural drainage management, quality and disposal issues in North America. Irrig. Drain. 56, S35-S45. doi:10.1002/ird

Maher, B.A., 1986. Characterisation of soils by mineral magnetic measurements. Phys. Earth Planet. Inter. 42, 76-92. doi:10.1016/S0031-9201(86)80010-3

Maher, B.A., 1998. Magnetic properties of modern soils and Quaternary loessic paleosols: paleoclimatic implications. Palaeogeogr. Palaeoclimatol. Palaeoecol. 137, 25-54. doi:10.1016/S0031-0182(97)00103-X

Mann, L., 1986. Changes in soil carbon storage after cultivation. Soil Sci. 142, 279-288.

Matamala, R., Jastrow, J.D., Miller, R.M., Garten, C.., 2008. Temporal changes in C and $\mathrm{N}$ stocks of restored prairie: Implications for carbon sequestration strategies. Ecol. Appl. 18, 1470-1488.

McCarthy, J.F., Ilavsky, J., Jastrow, J.D., Mayer, L.M., Perfect, E., Zhuang, J., 2008. Protection of organic carbon in soil microaggregates via restructuring of aggregate porosity and filling of pores with accumulating organic matter. Geochim. Cosmochim. Acta 72, 4725-4744. doi:10.1016/j.gca.2008.06.015

McLauchlan, K., Hobbie, S., Post, W., 2006. Conversion from agriculture to grassland builds soil organic matter on decadal timescales. Ecol. Appl. 16, 143-153.

McLauchlan, K.K., 2006. Effects of soil texture on soil carbon and nitrogen dynamics after cessation of agriculture. Geoderma 136, 289-299. doi:10.1016/j.geoderma.2006.03.053

McLauchlan, K.K., 2007. The Nature and Longevity of Agricultural Impacts on Soil Carbon and Nutrients: A Review. Ecosystems 9, 1364-1382. doi:10.1007/s10021005-0135-1

Monreal, C.M., Sultan, Y., Schnitzer, M., 2010. Soil organic matter in nano-scale structures of a cultivated Black Chernozem. Geoderma 159, 237-242. doi:10.1016/j.geoderma.2010.07.017

Morris, S.J., Bohm, S., Haile-Mariam, S., Paul, E. a., 2007. Evaluation of carbon accrual in afforested agricultural soils. Glob. Chang. Biol. 13, 1145-1156.

doi:10.1111/j.1365-2486.2007.01359.x

Mullins, C., 1977. Magnetic susceptibility of the soil and its significance in soil science -a review. J. Soil Sci. 28, 223-246.

Muneer, M., Oades, J., 1989. The Role of Ca-Organic Interactions in Soil Aggregate Stability . 111 . Mechanisms and Models. Aust. J. Soil Res. 27, 411-423. 
Nave, L.E., Swanston, C.W., Mishra, U., Nadelhoffer, K.J., 2013. Afforestation Effects on Soil Carbon Storage in the United States: A Synthesis. Soil Sci. Soc. Am. J. 77, 1035. doi:10.2136/sssaj2012.0236

Nierop, K.G.J.., Jansen, B., Verstraten, J.M., 2002. Dissolved organic matter, aluminium and iron interactions: precipitation induced by metal/carbon ratio, $\mathrm{pH}$ and competition. Sci. Total Environ. 300, 201-211. doi:10.1016/S0048-9697(02)002541

Novozamsky, I., Beek, J., 1978. Common solubility equilibria in soils, in: Bolt, G., Bruggenwert, M. (Eds.), Developments in Soil Chemistry A. Basic Elements. Elsevier Scientific Publishing, Amsterdam, pp. 96-125.

O’Brien, S.L., Jastrow, J.D., 2013. Physical and chemical protection in hierarchical soil aggregates regulates soil carbon and nitrogen recovery in restored perennial grasslands. Soil Biol. Biochem. 61, 1-13.

O’Brien, S.L., Jastrow, J.D., Grimley, D.A., Gonzalez-Meler, M.A., 2010. Moisture and vegetation controls on decadal-scale accrual of soil organic carbon and total nitrogen in restored grasslands. Glob. Chang. Biol. 16, 2573-2588.

Parton, W.J., Schimel, D.S., Cole, C. V, Ojima, D.S., 1987. Analysis of Factors Controlling Soil Organic Matter Levels in Great Plains Grasslands. Soil Sci. Soc. Am. J. 51, 1173-1179.

Percival, H.J., Parfitt, R.L., Scott, N.A., 2000. Factors Controlling Soil Carbon Levels in New Zealand Grasslands $\square$ : Is Clay Content Important $\square$ ? Soil Sci. Soc. Am. J. 64, $1623-1630$.

Plante, A.F., Conant, R.T., Stewart, C.E., Paustian, K., Six, J., 2006. Impact of Soil Texture on the Distribution of Soil Organic Matter in Physical and Chemical Fractions. Soil Sci. Soc. Am. J. 70, 287. doi:10.2136/sssaj2004.0363

Post, W., Kwon, K., 2000. Soil carbon sequestration and land-use change $\square$ : processes and potential. Glob. Chang. Biol. 6, 317-327.

Saiz, G., Bird, M.I., Domingues, T., Schrodt, F., Schwarz, M., Feldpausch, T.R., Veenendaal, E., Djagbletey, G., Hien, F., Compaore, H., Diallo, A., Lloyd, J., 2012. Variation in soil carbon stocks and their determinants across a precipitation gradient in West Africa. Glob. Chang. Biol. 18, 1670-1683. doi:10.1111/j.13652486.2012.02657.x

Schlesinger, W.H., Andrews, J.A., 2000. Soil respiration and the global carbon cycle. Biogeochemistry 48, 7-20. 
Schnitzer, M., McArthur, D.F.E., Schulten, H.-R., Kozak, L.M., Huang, P.M., 2006. Long-term cultivation effects on the quantity and quality of organic matter in selected Canadian prairie soils. Geoderma 130, 141-156. doi:10.1016/j.geoderma.2005.01.021

Six, J., Conant, R.T., Paul, E.A., Paustian, K., 2002. Stabilization mechanisms of soil organic matter $\square$ : Implications for C-saturation of soils. Plant Soil 241, 155-176.

Slobodian, N., Rees, K. Van, Pennock, D., 2002. Cultivation-Induced Effects on Belowground Biomass and Organic Carbon. Soil Sci. Soc. Am. J. 66, 924-930.

Sollins, P., Homann, P., Caldwell, B. a., 1996. Stabilization and destabilization of soil organic matter: mechanisms and controls. Geoderma 74, 65-105. doi:10.1016/S0016-7061(96)00036-5

Stewart, C.E., Paustian, K., Conant, R.T., Plante, A.F., Six, J., 2008. Soil carbon saturation: Evaluation and corroboration by long-term incubations. Soil Biol. Biochem. 40, 1741-1750. doi:10.1016/j.soilbio.2008.02.014

Tiessen, H., Stewart, J.W.B., Bettany, J.R., 1982. Cultivation Effects on the Amounts and Concentration of Carbon, Nitrogen, and Phosphorus in Grassland Soils. Agron. J. $74,831-835$.

Vadyunina, A., Babanin, V., 1972. Magnetic susceptibility of some soils in teh USSR. Sov. Soil Sci. 4, 588-599.

Virto, I., Barré, P., Chenu, C., 2008. Microaggregation and organic matter storage at the silt-size scale. Geoderma 146, 326-335. doi:10.1016/j.geoderma.2008.05.021

Vogel, C., Mueller, C.W., Höschen, C., Buegger, F., Heister, K., Schulz, S., Schloter, M., Kögel-Knabner, I., 2014. Submicron structures provide preferential spots for carbon and nitrogen sequestration in soils. Nat. Commun. 5, 2947.

doi:10.1038/ncomms3947

Von Haden, A.C., Dornbush, M.E., 2014. Patterns of root decomposition in response to soil moisture best explain high soil organic carbon heterogeneity within a mesic, restored prairie. Agric. Ecosyst. Environ. 185, 188-196.

doi:10.1016/j.agee.2013.12.027

Warncke, D., Brown, J., 1998. Potassium and other basic cations, in: Recommended Chemical Soil Test Procedures for the North Central Region. North Central Region Publication No. 221 (revised). University of Missouri Agricultural Experiment Station, Columbia, MO, pp. 31-33.

Watson, M., Brown, J., 1998. pH and lime requirements, in: Recommended Chemical Soil Test Procedures for the North Central Region. North Central Region 
Publication No. 221 (revised). University of Missouri Agricultural Experiment Station, Columbia, MO, pp. 13-16.

Whitney, D., 1998. Micronutrients: Zinc, iron, manganese, and copper, in: Recommended Chemical Soil Test Procedures for the North Central Region. North Central Region Publication No. 221 (revised). University of Missouri Agricultural Experiment Station, Columbia, MO, pp. 41-44.

Yu, J., Zhan, S., Wu, L., Chu, T., 1986. The magnetic susceptibility of the soil in subtropical and tropical China. Acta Pedol. Sin. 23, 50-56. 
Fig. 1 Plot of principal component scores summarizing correlations among edaphic factors by moisture class. Arrows represent variable loadings relative to each axis. Axis labels indicate the proportion of the total variation accounted for by each component.

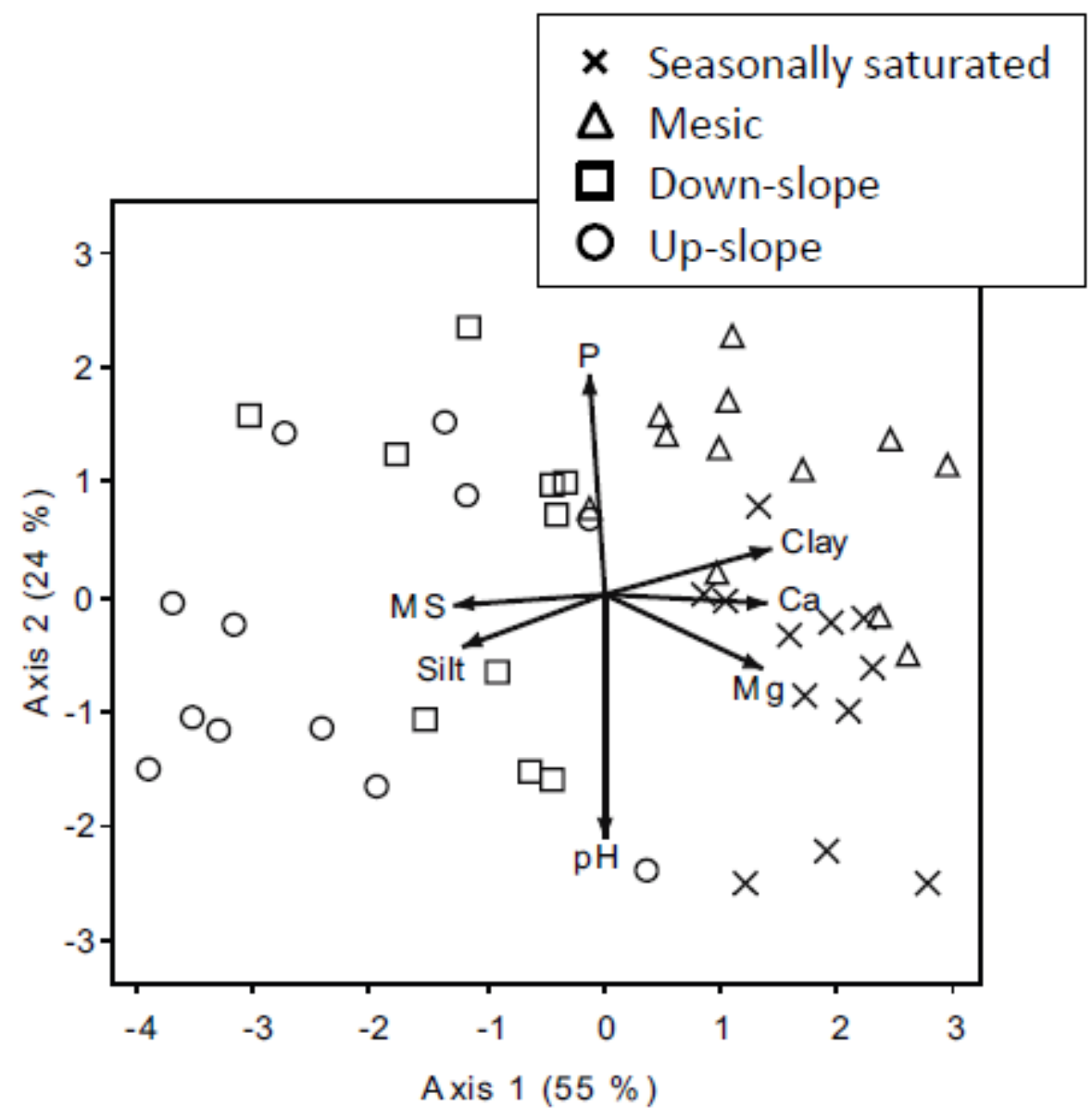


Fig. 2 Soil organic carbon (SOC) in $\mathrm{g} \mathrm{C} \mathrm{m}^{-2}$ ( $\log _{\mathrm{e}}$-transformed values) to a depth of 10 $\mathrm{cm}$ as a function of axis 1 from the principal component analysis. Slope $=0.11 \pm 0.01$; Intercept $=7.9 \pm 0.02 ; r^{2}=0.63 P<0.01$.

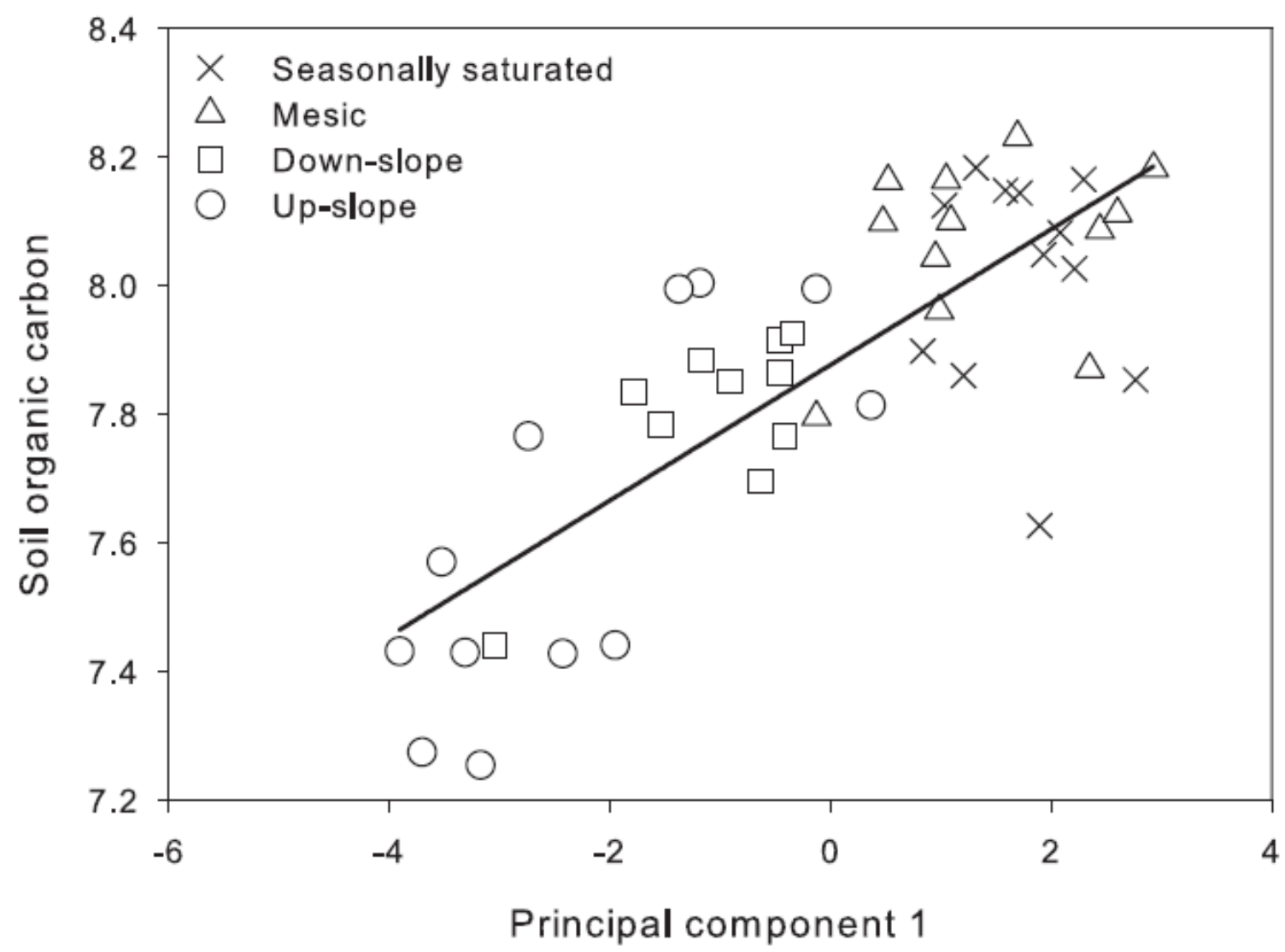


Fig. 3 Soil organic carbon (SOC) in $\mathrm{g} \mathrm{C} \mathrm{m}^{-2}$ ( $\log _{\mathrm{e}}$-transformed values) to a depth of 10 $\mathrm{cm}$ as a function of soil exchangeable $\mathrm{Ca}^{2+}\left(\log _{\mathrm{e}}\right.$-transformed values). Slope $=1.00 \pm$ $0.09 ;$ Intercept $=-0.27 \pm 0.73 ; r^{2}=0.74 ; P<0.01$.

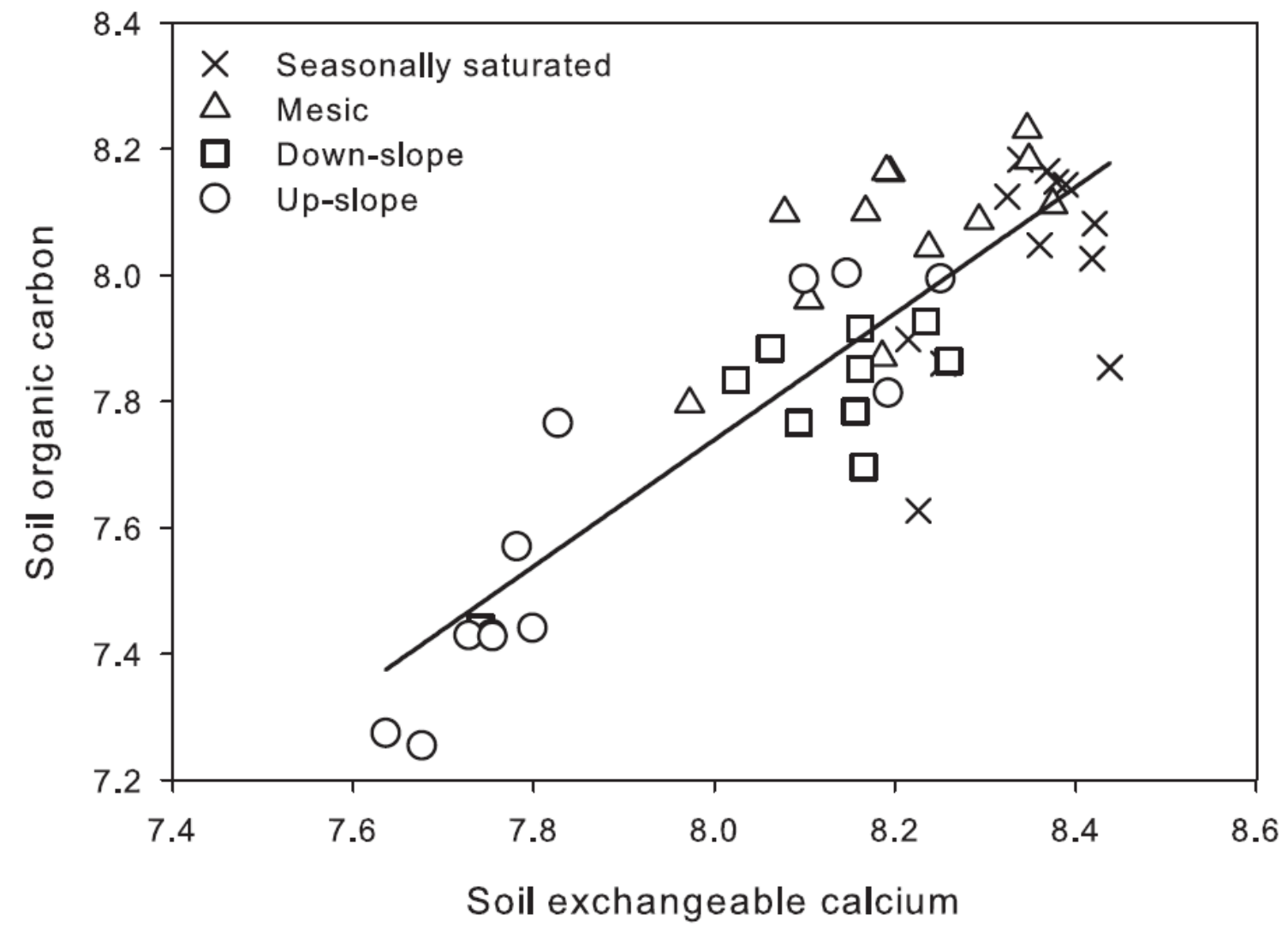


Table 1. Plot characteristics and moisture classification categories of the restored prairies.

\begin{tabular}{|c|c|c|c|c|c|c|c|}
\hline Plot & $\begin{array}{c}\text { Planting } \\
\text { date }\end{array}$ & $\begin{array}{l}\text { Plot } \\
\text { age } \\
\text { (y) }\end{array}$ & $\begin{array}{l}\text { Area } \\
\text { (ha) }\end{array}$ & $\begin{array}{l}\text { Moisture } \\
\text { category }\end{array}$ & $\begin{array}{c}\text { Elevation } \\
(\mathrm{m} \\
\left.\mathrm{AMSL}^{\mathrm{a}}\right)\end{array}$ & Soil series & Location \\
\hline 2 & $\begin{array}{c}\text { Spring } \\
1976\end{array}$ & 29 & 4.5 & Mesic & 227.2 & Wauconda & $\begin{array}{l}\text { Main } \\
\text { ring }\end{array}$ \\
\hline 4 & $\begin{array}{l}\text { Fall } \\
1977\end{array}$ & 27 & 6.5 & Mesic & 227.0 & Mundelein & $\begin{array}{c}\text { Main } \\
\text { ring }\end{array}$ \\
\hline 7 & $\begin{array}{c}\text { Spring } \\
1981\end{array}$ & 24 & 6.9 & Mesic & 227.0 & Mundelein & $\begin{array}{c}\text { Main } \\
\text { ring }\end{array}$ \\
\hline 10 & $\begin{array}{c}\text { Spring } \\
1983\end{array}$ & 22 & 21.5 & $\begin{array}{l}\text { Seasonally } \\
\text { saturated }\end{array}$ & 225.5 & Mundelein & $\begin{array}{l}\text { Main } \\
\text { ring }\end{array}$ \\
\hline 11 & $\begin{array}{c}\text { Spring } \\
1984\end{array}$ & 21 & 13.0 & $\begin{array}{l}\text { Seasonally } \\
\text { saturated }\end{array}$ & 225.5 & Drummer/Mundelein & $\begin{array}{l}\text { Main } \\
\text { ring }\end{array}$ \\
\hline 13 & $\begin{array}{c}\text { Spring } \\
1985\end{array}$ & 20 & 19.0 & $\begin{array}{l}\text { Seasonally } \\
\text { saturated }\end{array}$ & 225.5 & Drummer & $\begin{array}{l}\text { Main } \\
\text { ring }\end{array}$ \\
\hline \multirow{2}{*}{12} & \multirow{2}{*}{$\begin{array}{c}\text { Spring } \\
1984\end{array}$} & \multirow{2}{*}{21} & \multirow{2}{*}{13.4} & Up-slope & 226.2 & Wauconda & $\begin{array}{l}\text { Injector } \\
\text { ring }\end{array}$ \\
\hline & & & & Down-slope & 224.6 & Drummer & $\begin{array}{l}\text { Injector } \\
\text { ring }\end{array}$ \\
\hline \multirow{2}{*}{14} & \multirow{2}{*}{$\begin{array}{l}\text { Spring } \\
1985\end{array}$} & \multirow{2}{*}{20} & \multirow{2}{*}{7.7} & Up-slope & 229.2 & Wauconda & $\begin{array}{l}\text { Outside } \\
\text { rings }\end{array}$ \\
\hline & & & & Down-slope & 228.9 & Drummer & $\begin{array}{l}\text { Outside } \\
\text { rings }\end{array}$ \\
\hline \multirow{2}{*}{15} & \multirow{2}{*}{$\begin{array}{c}\text { Spring } \\
1986\end{array}$} & \multirow{2}{*}{19} & \multirow{2}{*}{20.3} & Up-slope & 236.5 & Ozaukee & $\begin{array}{c}\text { Outside } \\
\text { rings }\end{array}$ \\
\hline & & & & Down-slope & 230.1 & Drummer & $\begin{array}{c}\text { Outside } \\
\text { rings }\end{array}$ \\
\hline
\end{tabular}

${ }^{a}$ Above mean sea level 
Table 2. Edaphic properties in restored prairies grouped by moisture classification categories (means \pm standard errors, $n=3$ for each category). Means followed by the same letter within a row were not significantly different on the basis of post-hoc comparisons with Tukey-Kramer adjustments $(P>0.05)$.

\begin{tabular}{|c|c|c|c|c|}
\hline $\begin{array}{l}\text { Edaphic } \\
\text { properties * }\end{array}$ & $\begin{array}{l}\text { Seasonally } \\
\text { saturated }\end{array}$ & Mesic & Down-slope & Up-slope \\
\hline $\begin{array}{l}\text { Cation exchange capacity } \\
\left.\text { (meq } 100 \mathrm{~g}^{-1}\right)\end{array}$ & $33.3 \pm 0.3^{\mathrm{a}}$ & $30.0 \pm 0.4^{\mathrm{ab}}$ & $26.0 \pm 2.6^{\mathrm{ab}}$ & $22.1 \pm 3.6^{\mathrm{l}}$ \\
\hline $\mathrm{Ca}^{2+}(\mathrm{ppm})$ & $\begin{array}{l}4217 \pm \\
25^{\mathrm{a}}\end{array}$ & $\begin{array}{l}3694 \pm \\
74^{\text {ab }}\end{array}$ & $\begin{array}{l}3233 \pm \\
282^{\mathrm{ab}}\end{array}$ & $\begin{array}{l}2723 \pm \\
413^{\mathrm{b}}\end{array}$ \\
\hline $\mathrm{Mg}^{2+}(\mathrm{ppm})$ & $\begin{array}{l}1294 \pm \\
34^{\mathrm{a}}\end{array}$ & $1047 \pm$ & $\begin{aligned} 920 \pm \\
111^{\mathrm{b}}\end{aligned}$ & $\begin{aligned} 813 \pm \\
112^{\mathrm{b}}\end{aligned}$ \\
\hline $\mathrm{K}^{+}(\mathrm{ppm})$ & $\begin{array}{l}307 \pm \\
14^{\mathrm{a}}\end{array}$ & $\begin{array}{c}390 \pm \\
29^{\mathrm{a}}\end{array}$ & $\begin{array}{l}304 \pm \\
39^{\mathrm{a}}\end{array}$ & $\begin{array}{c}312 \pm \\
77^{\mathrm{a}}\end{array}$ \\
\hline $\mathrm{Na}^{+}(\mathrm{ppm})$ & $45.9 \pm 2.9^{\mathrm{a}}$ & $33.0 \pm 2.4^{\mathrm{b}}$ & $42.8 \pm 1.7^{\mathrm{ab}}$ & $39.0 \pm 3.2^{\mathrm{at}}$ \\
\hline $\mathrm{Fe}^{3+}(\mathrm{ppm})$ & $\begin{array}{l}115.8 \pm \\
23.6^{\mathrm{a}}\end{array}$ & $\begin{array}{l}110.1 \pm \\
28.1^{\mathrm{a}}\end{array}$ & $78.4 \pm 4.3^{\mathrm{a}}$ & $58.1 \pm 9.2$ \\
\hline $\mathrm{Mn}^{2+}(\mathrm{ppm})$ & $28.6 \pm 3.8^{\mathrm{a}}$ & $20.6 \pm 2.4^{\mathrm{a}}$ & $29.2 \pm 5.6^{\mathrm{a}}$ & $32.6 \pm 4.2^{c}$ \\
\hline $\mathrm{pH}$ & $6.7 \pm 0.2^{\mathrm{a}}$ & $6.1 \pm 0.1^{\mathrm{a}}$ & $6.4 \pm 0.3^{\mathrm{a}}$ & $6.6 \pm 0.1^{2}$ \\
\hline Available P (ppm) & $18.4 \pm 5.1^{\mathrm{a}}$ & $25.6 \pm 4.8^{\mathrm{a}}$ & $34.4 \pm 9.5^{\mathrm{a}}$ & $20.3 \pm 3.6$ \\
\hline Sand $(\%)$ & $9.7 \pm 1.1^{\mathrm{a}}$ & $12.8 \pm 1.9^{\mathrm{a}}$ & $12.5 \pm 0.8^{\mathrm{a}}$ & $13.7 \pm 0.4$ \\
\hline Silt (\%) & $55.5 \pm 2.0^{\mathrm{a}}$ & $48.5 \pm 1.6^{\mathrm{b}}$ & $60.8 \pm 0.9^{c}$ & $62.2 \pm 1.8$ \\
\hline Clay $(\%)$ & $34.8 \pm 1.0^{\mathrm{a}}$ & $38.7 \pm 0.4^{\mathrm{a}}$ & $26.7 \pm 1.6^{\mathrm{b}}$ & $24.2 \pm 2.2^{\mathrm{l}}$ \\
\hline Silt:clay & $\begin{array}{l}1.60 \pm \\
0.10^{\mathrm{a}}\end{array}$ & $\begin{array}{l}1.26 \pm \\
0.04^{\mathrm{a}}\end{array}$ & $\begin{array}{l}2.31 \pm \\
0.17^{\mathrm{ab}}\end{array}$ & $0.34^{2.66 \pm}$ \\
\hline Gravimetric moisture (\%) & $50.9 \pm 2.3^{\mathrm{a}}$ & $43.2 \pm 0.5^{\mathrm{ab}}$ & $41.0 \pm 3.9^{\mathrm{ab}}$ & $39.3 \pm 0.2^{\mathrm{b}}$ \\
\hline $\begin{array}{l}\text { Magnetic susceptibility }\left(\times 10^{-}\right. \\
\left.{ }^{8} \mathrm{~m}^{3} \mathrm{~kg}^{-1}\right)\end{array}$ & $12.5 \pm 0.5^{\mathrm{a}}$ & $17.3 \pm 2.8^{\mathrm{ab}}$ & $29.2 \pm 2.7^{\mathrm{bc}}$ & $31.9 \pm 4.1$ \\
\hline $\begin{array}{l}\text { SOC stocks }\left(\mathrm{g} \mathrm{m}^{-2} \times 10-\mathrm{cm}\right. \\
\text { depth) }\end{array}$ & $\begin{array}{l}3059 \pm \\
261^{\mathrm{a}}\end{array}$ & $3213 \pm 9^{a}$ & $\begin{array}{l}2397 \pm \\
151^{\mathrm{a}}\end{array}$ & $\begin{array}{l}2110 \pm \\
376^{\mathrm{a}}\end{array}$ \\
\hline
\end{tabular}

* Variation due to the random effect of plot age in the mixed-model one-way ANOVAs was either zero or not significant $(P>0.05)$ for all edaphic properties except the percentage of silt-sized particles. However, plot age was retained in the model and in calculations of mean separations for all edaphic properties because it was a component of the study and sampling design that could not otherwise be controlled. 
Table 3. Person product-moment correlations among $\log _{\mathrm{e}}$-transformed variables retained in principal component analysis. Bold face indicates significance at $P<0.05$.

\begin{tabular}{lrrrrrrr}
\hline & \multicolumn{1}{l}{$\mathrm{MS}^{\mathrm{a}}$} & \multicolumn{1}{l}{$\mathrm{l} H$} & \multicolumn{1}{l}{$\mathrm{C}$} & \multicolumn{1}{l}{$\mathrm{Ca}$} & \multicolumn{1}{l}{$\mathrm{l} g$} & \multicolumn{1}{l}{ Silt } & \multicolumn{1}{l}{ Clay } \\
\hline $\mathrm{MS}^{\mathrm{a}}$ & & 0.02 & 0.02 & $\mathbf{- 0 . 7 3}$ & $\mathbf{- 0 . 6 7}$ & $\mathbf{0 . 5 8}$ & $\mathbf{- 0 . 7 2}$ \\
$\mathrm{pH}$ & 0.02 & & $\mathbf{- 0 . 6 0}$ & 0.07 & 0.27 & 0.22 & -0.18 \\
$\mathrm{P}$ & 0.02 & $\mathbf{- 0 . 6 0}$ & & 0.04 & -0.21 & 0.08 & -0.03 \\
$\mathrm{Ca}$ & $\mathbf{- 0 . 7 3}$ & -0.07 & 0.04 & & $\mathbf{0 . 9 3}$ & $\mathbf{- 0 . 5 4}$ & $\mathbf{0 . 7 5}$ \\
$\mathrm{Mg}$ & $\mathbf{- 0 . 6 7}$ & 0.27 & -0.21 & $\mathbf{0 . 9 3}$ & & -0.50 & $\mathbf{0 . 7 2}$ \\
$\mathrm{Silt}$ & $\mathbf{0 . 5 8}$ & 0.22 & 0.08 & $\mathbf{- 0 . 5 4}$ & $\mathbf{- 0 . 5 0}$ & & $\mathbf{- 0 . 8 6}$ \\
Clay & $\mathbf{- 0 . 7 2}$ & -0.18 & -0.03 & $\mathbf{0 . 7 5}$ & $\mathbf{0 . 7 2}$ & $\mathbf{- 0 . 8 6}$ & \\
\hline
\end{tabular}

${ }^{\mathrm{a}}$ Magnetic susceptibility 
Table 4. Results for regressions of soil organic carbon (SOC) stocks with the first two axes from the principal component analysis (PCA; Fig. 1), each of the variables included in the PCA, and plot age. All values, including SOC, were $\log _{\mathrm{e}}$-transformed prior to all regression analyses.

\begin{tabular}{lcrc}
\hline & Parameter estimate & \multicolumn{1}{c}{$P$} & $r^{2}$ \\
\hline Axes 1 \& 2 & -- & $<0.01$ & 0.77 \\
\hline Axis 1 & 0.11 & $<0.01$ & 0.63 \\
Axis 2 & 0.07 & 0.01 & 0.14 \\
$\mathrm{Ca}^{2+}$ & 1.00 & $<0.01$ & 0.74 \\
Clay $_{\mathrm{Mg}^{2+}}$ & 0.84 & $<0.01$ & 0.52 \\
$\mathrm{MS}^{\mathrm{b}}$ & 0.75 & $<0.01$ & 0.48 \\
Silt & -0.39 & $<0.01$ & 0.43 \\
Plot age & -1.27 & $<0.01$ & 0.32 \\
P & 0.04 & $<0.01$ & 0.22 \\
pH & 0.17 & 0.01 & 0.15 \\
\hline
\end{tabular}

${ }^{\text {a }}$ Parameter estimates derived from the separate regressions for each axis. $P$-value and $r^{2}$ are from the overall regression including both axes.

${ }^{\mathrm{b}}$ Magnetic susceptibility 